\title{
Cell Division Cycle-Associated Protein 7
}

National Cancer Institute

\section{Source}

National Cancer Institute. Cell Division Cycle-Associated Protein 7. NCI Thesaurus. Code C152970.

Cell division cycle-associated protein 7 (371 aa, $\sim 43 \mathrm{kDa}$ ) is encoded by the human CDCA7 gene. This protein is involved in the modulation of cell proliferation. 